\title{
A LOUCURA \\ FEITA LITERATURA EM RENATO POMPEU E RicARDO PigLiA*
}

Elizabeth da Penha Cardoso**

Resumo: O presente trabalho articula uma leitura dos romances Quatro-Olhos, de Renato Pompeu, e A cidade ausente, de Ricardo Piglia, com o objetivo de apontar o modo como os romancistas constroem suas ficções nas confluências entre o literário e a loucura. É nessas dobras que ambos transgridema narratividade convencional e instauram seus livros na fragmentação, na verborragia, constituída na multiplicidade textual, e no aparente caos da fala louca.

Palavras-chave: Literatura e loucura. Renato Pompeu. Ricardo Piglia.

\section{LITERATURA E LOUCURA}

0 s encontros entre loucura e literatura não são raros nem novos na tradição literária. Desde Nau de loucos (Das Narrenschiff), de Sebastian Brandt (1494), e Don Quijote de la Mancha, de Miguel Cervantes (1605), até o surrealismo de Breton, a representação da loucura tem sido tema constante e central para vários prosadores e poetas. Assim também ocorre nas artes plásticas, com Bosch, no final do século XV, até Salvador Dali, no século $\mathrm{XX}$, para citar dois artistas reconhecidamente dedicados a revelar os contornos da desrazão.

A tendência firma-se paulatinamente e, a partir do final do século XIX, é raro o romance que não imprima algum nivel de transtorno psíquico em suas personagens. Desde as abordagens diretas do tema, como em O alienista (1881), de Machado de Assis, e no conto "Sorôco, sua mãe, sua filha" (1962), de Guimarães Rosa, até a depressão traduzida em modos casmurros em romances de Macha-

Este artigo é parte do resultado da pesquisa de pós-doutorado desenvolvida pela autora, durante o ano de 2014 , no Programa de Estudos Pós-Graduados em Literatura e Crítica Literária da PUCSP, sob o título Literatura latino-americana e loucura: a escrita do delírio em Renato Pompeu e Ricardo Piglia, com apoio da Capes.

** Pontifícia Universidade Católica de São Paulo (PUC-SP) - São Paulo - SP - Brasil. E-mail: elizcardoso@terra.com.br 
do; a angústia íntima causada pelas desigualdades impressas em Graciliano Ramos; a histeria provocada pelo cotidiano das mulheres reprimidas por seus papéis sociais em Clarice Lispector e a perversão rasgada em Nelson Rodrigues, para ficarmos em nomes canônicos da literatura brasileira. Ainda poderíamos citar Lima Barreto, Dyonélio Machado, Maura Lopes Cançado, Sérgio Sant'Anna, Carlos Sussekind e, mais recentemente, Lourenço Mutarelli, e mesmo assim deixaríamos vários nomes de fora.

Do lado argentino, os próprios precursores de Piglia, Roberto Arlt e Macedonio Fernández (referência direta em A cidade ausente, que seria uma versão do romance Museo de la novela de la eterna, de 1967) reservam atenção especial ao tema. Na literatura do cânone universal, o gênero romance, que tem em Emma Bovary seu marco da instabilidade emocional, chega ao limite com a produção de Kafka e Joyce. O último é apontado por Piglia (2000) como o maior escritor do século XX, justamente por ter elevado a psicanálise a uma metodologia da escritura e não apenas como fonte de informação para traços de caráter das personagens. Outros pesquisadores da obra de Piglia têm indicado o tema da loucura como central em sua obra, e um exemplo é Marcelo Gobbo. Durante entrevista a Jorge Fornet (2004), Piglia também reflete sobre a presença da desrazão em sua prosa e afirma se interessar pela loucura enquanto "mecanismo alternativo de construção de realidades ficcionais" de modo análogo à literatura:

La locura es una realidad virtual; aquel que uno llama loco es el que vive en un mundo paralelo, y eso es muy fascinante para un escritor porque la ficción es en realidad una sicosis controlada. Uno va y vuelve a un espacio del que otro no vuelve. Si nos pusiéramos en ese plano podríamos decir que la literatura tiene que ver con esa experiencia, pero no en el sentido romántico de que para ser un escritor hay que estar loco y ese tipo de cosas... Yo soy lo contrario de eso pero sí me interesan los mecanismos alternativos en la construcción de realidades ficcionales, lo que es común en la demencia y en la literatura. No sé qué sentido tiene en mi literatura aparezcan esos personajes sicóticos. No sé qué motivo hay. Sobre todo en La ciudad ausente... No sé por qué en mi narrativa aparecen esas experiencias límites. Espero no volverme loco $^{1}$ (FORNET, 2004, p. 328-329).

Já Shoshana Felman (1985) adota a perspectiva do leitor, quando afirma que os encontros entre a literatura e a loucura se dão por serem ambas "irredutíveis à interpretação". Por trás de tal resistência, está a noção de que a razão, tão valorizada no pensamento aristotélico e cartesiano, é limitada, pois exclui a ambiguidade e as contradições. Vale lembrar um dos princípios de Aristóteles - nada pode ser diferente de si mesmo - que cai por terra com as pesquisas de Freud, que nos apresenta o sujeito cindido.

Em sua História da loucura, Michel Foucault (1972, p. 258-259) faz menção à linguagem como elemento central na configuração da loucura:

\footnotetext{
"A loucura é uma realidade virtual; aquele que alguns chamam de louco está vivendo em um mundo paralelo, o que é muito excitante para um escritor porque a ficção é na realidade uma psicose controlada. Tem gente que vai e volta de uma dimensão que outros não retornam. Se nos colocássemos nessa dimensão, poderíamos dizer que a literatura tem a ver com essa experiência, mas não no sentido romântico de que ser um escritor é preciso ser louco e esse tipo de coisa... Eu sou o oposto disso, mas me interessam mecanismos alternativos na construção de realidades ficcionais, o que é comum na demência e na literatura. Eu não sei qual o sentido desses personagens psicóticos que aparecem em minha literatura. Eu não sei qual o motivo. Especialmente em A cidade ausente ... eu não sei por que, em minha narrativa, aparecem essas experiências limites. Espero não enlouquecer" (tradução nossa).
} 
Maravilhosa lógica dos loucos, que parece zombar da dos lógicos, pois assemelha-se a esta, ou melhor, porque é exatamente amesma e porque, no recanto mais secreto da loucura, na base de tantos erros, de tantos absurdos, de tantas palavras e gestos sem seqüência, finalmente se descobre a perfeição, profundamente oculta, de um discurso. [...] A linguagem última da loucura é a da razão, mas envolvida no prestígio da imagem, limitada ao espaço aparente que a loucura define, formando assim, ambas, exteriormente à totalidade e à universalidade do discurso, uma organização singular, abusiva, cuja particularidade obstinada perfaz a loucura.

E chega mesmo a afirmar que:

A linguagem é a estrutura primeira e última da loucura. Ela é sua forma constituinte, é nela que repousam os ciclos nos quais ela enuncia sua natureza. $O$ fato de a essência da loucura poder ser definida, enfim, na estrutura simples de um discurso não a remete a uma natureza puramente psicológica, mas lhe dá ascendência sobre a totalidade da alma e do corpo; esse discurso é simultaneamente linguagem silenciosa que o espírito formula a si mesmo na verdade que the é própria e articulação visível nos movimentos do corpo (FOUCAULT, 1972, p. 263).

Freud já havia estabelecido essa relação e dedicou grande parte de sua obra ao estudo de como o inconsciente interfere na vida consciente, como ele se faz presente, como se faz ouvir, como comunica seus conteúdos, utilizando a linguagem e seus mecanismos. Essa abordagem produziu alguns de seus principais conceitos.

Os dois primeiros deles já aparecem em 1900, na Interpretação dos sonhos. Trata-se da condensação e do deslocamento, os quais Freud apontou como sendo os mecanismos fundamentais dos processos primários do inconsciente e que estão presentes na formação de sonhos, lapsos e chistes. São caminhos abertos pelo conteúdo inconsciente para se tornarem conscientes, burlando o sistema de censura. Na condensação, alguns elementos do pensamento (formadores) do sonho são omitidos, divididos, comprimidos ou combinados para juntos criarem uma nova unidade (sonho) que, por relação de similaridade em cadeias associativas, remete aos seus aspectos formadores. Já o deslocamento, por contiguidade, cria um novo elemento por meio da substituição, justaposição ou ênfase de atributos fundamentais do pensamento onírico que se tornam secundários e, por isso mesmo, de difícil interpretação no sonho.

Quase simultaneamente, Freud publica Sobre a psicopatologia da vida cotidiana (2006 [1901]), obra na qual afirma que a condensação e o deslocamento também estão presentes na elaboração da memória e do ato falho, além do chiste e do lapso. O psicanalista argumenta que

[...] a situação [no ato falho e o sonho] é a mesma: por caminhos incomuns $e$ através de associações externas, os pensamentos inconscientes expressam-se como modificação de outros pensamentos. As incongruências, absurdos e erros do conteúdo do sonho, em conseqüência dos quais é dificil reconhecer o sonho como um produto da atividade psíquica, originam-se da mesma maneira [...] que os erros comuns de nossa vida cotidiana; tanto aqui quanto ali, a aparência de uma função incorreta explica-se pela peculiar interferência mútua entre duas ou mais funções corretas (FREUD, 2006, p. 271). 
Nessa obra, o psicanalista ainda relaciona vários tipos de esquecimento, lapso e engano para ilustrar o quanto o sujeito elabora a memória, reinventando-a. Para Freud, memória não é preservação de lembranças, mas resultado da diferença entre o consciente e o inconsciente - o sujeito lembra o que escapa ao sistema consciente.

É por causa de conceitos como esses que Lacan afirmará que o inconsciente se estrutura como a linguagem e aprofundará os estudos de Freud, associando-o à retórica e à linguística, especialmente a de Jakobson (1975). No fluxo dessas relações, ele apontará que a condensação corresponde à metáfora e o deslocamento, à metonímia, chegando a afirmar que o lapso é um discurso bem-sucedido (LACAN, 1998, p. 269).

Não se discute que o texto fragmentado, as elipses, as metáforas e as metonímias não precisam do saber psicanalítico para serem localizadas e analisadas. No entanto, quando estão em questão romances escritos por autores envolvidos teoricamente ou pessoalmente com a loucura - Piglia tem ensaios sobre a psicanálise, enquanto Pompeu passou por surtos psíquicos e internações - e obras que colocam a loucura em evidência, tais elementos narrativos ganham outra dimensão, a qual solicita analogias com o saber psicanalítico, de modo a favorecer sua interpretação.

Nesse sentido, aqui, entende-se a "fala louca" - de algum modo presente no sujeito inconsciente que habita a todos - atravessada pela ilogicidade e por incertezas, denunciando a impossibilidade de conhecimento e tradução do mundo, mas também portadora de uma comunicabilidade, de um conhecimento. No entanto, trata-se de um saber que resiste e escapa a interpretações fechadas. Com essa dinâmica, a fala do louco subverte o discurso institucional e legal, reorganizando o "real". Nesse caos aparente, surge a possibilidade de o louco encontrar um lugar social e linguístico para atuar como sujeito e vencer os aparelhos repressivos (subjetivos e institucionais). Não por acaso, Pompeu e Piglia configuram a loucura fragmentada e caótica como metáfora de resistência à ditadura militar no Brasil e na Argentina, respectivamente, durante as décadas de 1960, 1970 e 1980².

Antes de partirmos para a análise das obras, cabe observar que a referência ao termo "fala louca" está vinculada à ideia de alucinação e deve-se à necessidade de indicar nos romances de Pompeu e Piglia o uso de uma linguagem caótica, proferida por personagens internadas em manicômios ou sob suspeita de surto, para configurar suas peculiares literaturas. Sublinho que não está em questão diagnosticar as personagens, mas, sim, indicar como os autores aproveitam a linguagem da loucura para estruturar suas narrativas. Mesmo assim, alguns esclarecimentos são necessários.

Alucinar é reagir a algo que não existe; ver e sentir algo que está ausente para os outros (DALGALARRONDO, 2000). As personagens de Quatro-Olhos e A cidade ausente fazem o contrário - reagem a algo real, a ditadura militar -, porém o que os romancistas querem evidenciar não é a reação pura e simples, mas a solidão de quem reage, devido ao silêncio imposto (por meio do medo) sobre o tema proibido (não concordar com a repressão militar). Sendo assim, Quatro-Olhos e as personagens de Piglia acabam em uma alucinação, digamos, manipulada, pois

2 Não vamos aprofundar a representação desses momentos históricos nos romances em questão, pois não é esse o objetivo do artigo. Mas, conforme elaborado no sumário das obras, apresentado nas páginas seguintes, é importante apontar que os manicômios, instituições prisionais e clínicas, além de seus métodos de tratamento, nos romances, compõem uma metáfora dos últimos regimes ditatoriais no Brasil e na Argentina (entrevista/interrogatório, choque elétrico/tortura, internação/prisão, literário/fala louca etc.). Esse paralelo se dá justamente nas dobras entre literatura e loucura, que aqui procuramos indicar. 
reagem a um fenômeno (invisivel) que está acontecendo, supostamente, em segredo, nos porões da sociedade. Por isso são loucos: percebem, sentem e sofrem uma realidade que não existe, ou melhor, que está proibida de ser percebida. Daí a ironia, pois se sabe da existência concreta e sangrenta da repressão militar.

Nesse ponto os romancistas operam um importante deslocamento - trocam as prisões militares por hospícios, manicômios e clínicas. Não se trata de um recurso para burlar a censura (Piglia, por exemplo, escreve no período democrático), mas, sim, de criar verossimilhança para a estrutura narrativa fora dos padrões lineares e hierárquicos que os narradores praticam. Sendo loucos, falam como loucos, organizam suas ideias como loucos, e isso determina o enredo dos livros, como a não linearidade e o deambulismo análogo ao recurso estético dos capítulos de Quatro-Olhos e o ruído delirante das múltiplas vozes presentes no romance de Piglia, seja na fala enciclopédica das personagens, na confluência de inúmeras citações de outras obras literárias ou no recurso da história dentro da história, como veremos a seguir.

\section{A palavra poética nas dobras da loucura}

Em Quatro-Olhos, de Renato Pompeu ${ }^{3}$, publicado em 1976, a personagem que dá nome ao título ganha esse apelido no manicômio onde passa quatro meses, depois de ser presa indevidamente, apenas porque a esposa, que era militante política, foge com medo da repressão militar. E, de fato, logo após sua saída, a polícia invade a casa e, na falta da mulher, leva o marido: "Vamos então esperar por ela, senão vai você mesmo" (POMPEU, 1976, p. 136), responde o policial quando Quatro-Olhos avisa que ela havia ido embora. Antes de partir, os militares encontram e confiscam o manuscrito do livro que Quatro-Olhos vinha escrevendo há 13 anos. "[...] passei no mínimo três a quatro horas todos os dias, com exceção de um ou outro sábado e de certa segunda-feira, escrevendo não me lembro bem se romance ou um livro de crônicas" (POMPEU, 1976, p. 15). Sua obsessão torna-se recuperar esses escritos.

Sabemos, no final do romance, que ele fica preso apenas por algumas horas e que seu grande trauma, o gatilho que desencadeia a loucura, foi o fato de os militares terem confiscado seus manuscritos e desaparecido com eles. Ou seja, a concretização da censura mais crassa. Reconstituindo a escrita fragmentada, percebe-se que durante os três meses seguintes, entre a apreensão do romance e a internação, Quatro-Olhos perambula pela cidade em busca de seus escritos, perseguindo folhas soltas que as pessoas dizem ter visto em pontos diferentes da cidade de São Paulo, servindo aos objetivos mais banais, como embrulhar carne, ou simplesmente jogadas no lixo. Sem sucesso em sua reconstituição da obra, ele acaba no manicômio e, uma vez internado, tenta reescrevê-la, mas não consegue lembrar-se de quase nada.

Sua alta parece estar baseada na cura, mas a última frase, ironicamente, indica que a obsessão persiste: " $E$ logo descobriu o que tinha que fazer. Escrever

\footnotetext{
Pompeu (1941-2014) nasceu em Campinas, São Paulo, foi jornalista atuante na grande imprensa (Folha de S.Paulo, Jornal da Tarde, revista Veja), ganhou três Prêmios Abril e um Prêmio Esso de Jornalismo. Como escritor, teve 22 livros publicados, entre ficção e não ficção. Até sua morte colaborou com as revistas Caros Amigos, Carta Capital e nos jornais Diário do Comércio e Diário de S. Paulo, além de manter um blog. Entre os livros publicados, destacam-se os romances Quatro-Olhos (1976), SambaEnredo (1992) e O mundo como obra de arte criada pelo Brasil (2008). E de não ficção, Memórias da loucura (1983), Globalização e justiça social (1996), Canhoteiro: o homem que driblou a glória (2002). A questão da loucura é um tema que interessou pessoalmente ao autor, que teve histórico de internações psiquiátricas.
} 
outra vez o livro" (POMPEU, 1976, p. 188). O jogo com os títulos dos três capítulos já dá a medida da perspectiva ambígua que a loucura ocupa na obra. "Dentro", "Fora" e "De volta" do quê, de onde? Inicialmente, o leitor imagina que do hospício, mas não faz sentido porque o "Fora" é justamente dentro do manicômio. Outra hipótese é que se trata da loucura, mas como o "Fora", que aborda o cotidiano no hospício, poderia ser fora da loucura? A hipótese mais plausivel é que a personagem está, sai e volta do uso criativo da linguagem, sua principal estratégia de sobrevivência. Ele está dentro, fora e de volta ao seu romance, que também é onde o leitor permanece ciclicamente preso.

A segunda parte de Quatro-Olhos é dedicada ao cotidiano da vida no hospício. E muitos dos internos são descritos por Quatro-Olhos. Salvo exceções, essas descrições trazem uma perspectiva peculiar da realidade das instituições manicomiais, indo além da denúncia de maus-tratos e dando atenção para o conteúdo político e estético do comportamento do doente mental. No trecho a seguir, Quatro-Olhos descreve Regismundo, que com sua megalomania apresenta similaridades com os ditadores:

Cabelos voejando ritmados, pingando ouro do nariz, Regismundo empreitava diabruras com o real. Enquanto o mundo chão teimava em encrespar-se, pois parecia aspirar em espiral, com idas e voltas, revoltas e contravoltas, persistia o sábio Regismundo em assomar-se direto, convencido por loucura racional ser o não-torto o menos comprido e assim singular, certificado de que era o único certo, não se lhe antolhava outro modo, só o seu era dado; e, conforme o mundo marchava aqui e acolá, Regismundo não despencava, pois por vezes desvanecia-se no encontro entre seus ângulos retos e o caráter obtuso e obliquo do que lhe ocorria por fora. Dava-se então a fumaças: "Eu não disse?", avisava todo cheio de bigodes, espumejando-se no gozo; fruía deliciado o momentoso encontro, sorvendo em nirvana o mundo por um canudinho. "É o que sempre falei”, defluía como baba de um canto oral. Quando porém, como sói, se desperdia o mundo em rolos e desenrolos, em tramas e tramoias, então casquinava Regismundo menos visguento, mais líquido e correntio desabava o ar por língua e dente: "São todos uns inocentes", azedava. Não o dissessem udenista, que o era mas não engolia, o era por criação no aconchego liberal que não percebia agrário-exportador; suas ventosidades traíam o antigo perfume quando se descadeirava espremido em hora de necessidade. Pelo contrário, justificava-se às avanças, sentia o mundo cruel a deixa-lo só na frente (POMPEU, 1976, p. 148-149).

Os dois primeiros períodos trazem imagens inusitadas do louco. Para os cabelos sujos e despenteados, um voo ritmado. Para a coriza e o catarro, um ouro líquido. Para a loucura, "diabruras com o real", a "loucura racional". Essa primeira parte está alinhada com uma espécie de missão que Pompeu se autoimpõe no livro: revelar a beleza que a loucura agrega. Mas, na sequência, temos toda a ironia do narrador que não poupa ninguém. E o louco romantizado torna-se apenas louco, um megalomaníaco, para depois se transformar em um ser politizado. Em Quatro-Olhos, essas três dimensões são constantes e simultâneas.

A referência à União Democrática Nacional (UDN) é interessante. Trata-se de um partido conservador, fundado em 1945 e que teve suas atividades encerradas pelo golpe militar. O que fica aqui irônico é a lembrança do lema do partido 
- "O preço da liberdade é a eterna vigilância" - que satiriza a condição manicomial de Regismundo, a do própio Quatro-Olhos e, metaforicamente, da população em geral sob o comando do militares

O deambulismo, andar compulsivamente e sem propósito, é outro elemento da loucura que serve para Pompeu imprimir literariedade ao seu texto. Ele associa o deambulismo à procura pelo manuscrito. Isso se dá de dois modos. Primeiro, ao relacioná-los no âmbito físico e concreto, o deambular do louco e o caminhar de Pompeu por toda São Paulo à procura das páginas de seu manuscrito confiscado. Ou seja, a procura da escrita por meio de um método de loucos: andar sem rumo. Já se tem aí uma imagem inspiradora e clássica do ato de criação literária, como se o texto poético surgisse de um entregar-se ao movimento inconsciente, algo parecido com o pregado pelos surrealistas. Mas há outra dimensão nessa associação. Trata-se de a escrita fragmentada, circular, aparentemente sem lógica ou continuidade, especialmente localizada na primeira parte do romance, encontrar eco na arte de deambular dos internos do manicômio: são trajetórias que só ganham sentido para o observador/leitor sensivel e capaz de entender essa lógica peculiar.

Misturavam-se a Opontolegário outros deambuladores, sem trombadas; aquela engrenagem de gente funcionava macia, sempre se formava ao cair da noite, hora preferida para o andar sem destino. Os caminhos eram sempre os mesmos para cada um e seria possivel traçar um mapa das deambulações, mas os atendentes só viam a coisa em pedaços, nunca acompanhavam uma volta inteira e portanto thes parecia sem nexo a andadura. Limitavam-se a anotar no livro de ocorrências (POMPEU, 1976, p. 169).

Os atendentes não percebem a cena em toda a sua extensão, mas para quem sabe ler a deambulação na sua completa expressão de sentido (como faz o narrador), ela pode ser "a felicidade, enfim, escorrendo pelos pés; só prestando atenção nos pés, pisar ou evitar a risca, crescer dentro da gente a posse do mundo" (POMPEU, 1976, p. 168). Essa plenitude que os internos encontravam na deambulação é a mesma que Quatro-Olhos encontrava na escrita.

Muito naturalmente, assim, aos 16 anos, já no científico, me pus também a escrever, para criar um mundo correto em meio ao mundo falso em que vivia. Nesse livro eu punha coisas que vinham de fora de mim, é verdade, mas eram pedaços significativos do que estava em volta, que obedeciam à minha lei interna; todo o resto do mundo externo eu ignorava como irreal, só assimilando o que estivesse de acordo com minha lógica (POMPEU, 1976, p. 110).

Depois de perder a mulher e o manuscrito para a repressão da ditadura militar, ele une as duas ações expressivas (deambular e escrever) indicadas anteriormente, passando a zanzar pela cidade em busca do livro perdido.

No entanto, para além do gesto, vejamos como Pompeu traz a fala louca, propriamente dita, para seu texto. No trecho a seguir, a poética imagem de um autor que vê seu livro concretamente espalhado pela rua, lido e comentado por leitores, é atravessada pelo caos da linguagem desorganizada e verborreica que conforma uma cena surreal:

[...] era o meu livro jogado no banco, um desses bancos de cinco lugares, e o livro estava lá, pelo menos a pessoa me garantiu. Ou melhor, estivera, pois 
muitas folhas sairam pelas janelas ou caíram pelos degraus porta afora; alguns passageiros puderam mesmo avaliar o sentido e a velocidade das correntes de vento sobre o Ferreira e a Água Podre, a partir do movimento do meu livro perdido no ar. As folhas, aliás, andaram indo e vindo, nunca no mesmo ritmo, mas não se haviam espalhado em todas as direções, apenas em algumas. A pessoa estava me contando que tinha podido ler algumas frases, tendo chamado sua atenção a frequência de períodos com vírgula no meio e ponto no fim e lembrar-se de ter lido algumas palavras em que aparecia a letra D. [...] Descobri porém algumas folhas no meio das rosas na ilha da avenida; tinha chovido, estavam descoradas e ilegiveis, com manchas de sangue do homem que ali morrera. Muito antes dos jesuitas, os índios já moravam ali em aldeia e talvez eles tivessem plantado as flores, mas eu duvido e até faço pouco [...] (POMPEU, 1976, p. 22).

Os sentidos e as cores compõem um quadro marcante. Folhas dos manuscritos espalhados desde dentro do ônibus para as ruas e os bairros, deixando um rastro que torna o vento concretude. Traços gráficos, como a vírgula e a letra D, ganham relevância aleatória e inexplicável. As pinceladas de vermelho das rosas e do sangue dramatizam o cenário que, sem mais avisos, remonta ao Brasil colonial. Note-se como o narrador toma para si a recordação de outras pessoas e condensa as informações que the deram com sua memória sobre a lembrança dos outros, apropriando-se dela e delineando o Brasil Colônia.

O mesmo mecanismo aparece em A cidade ausente (1992), de Ricardo Piglia ${ }^{4}$. No romance do argentino, a função narrativa é realizada por uma máquina-mulher, dona de uma voz louca, narrando fatos que apenas ela vê ou antevê, burlando as tentativas do Estado dedicado a reprimir e controlar a circulação da informação. A narrativa em terceira pessoa, ambientada em Buenos Aires, é protagonizada pelo jornalista Miguel Mac Kensey, ou apenas Junior, receptor das informações dessa misteriosa mulher/máquina que transmite relatos de assassinatos e perseguições. Ao longo do romance, Junior tenta encontrar essa mulher que ora está internada em um suposto manicômio, onde é submetida a sessões de choques elétricos, ora em um museu.

A fortuna crítica sobre o romance vem apontando, e o próprio Piglia admite, que essa mulher, Elena, é referência à obra e à biografia do escritor argentino Macedonio Fernández (1874-1952) que, depois da morte da sua esposa, passou a ter uma vida errante e pouco documentada. Segundo depoimentos de Jorge Luis Borges, seus textos foram deixados nos vários locais onde viveu e parte de sua obra teve apenas registro oral. Essa oralidade, como já apontou Graciela Speranza (2004, p. 31), está presente em Piglia.

[...] Piglia señala en Macedonio aquello que bien podría definir por extensión su propia obra: una relación peculiar entre pensar y narrar, el estilo oral que nunca es lexical sino que se juega en la sintaxis y en el ritmo de la frase, un

4 Piglia nasceu em 1940, em Androgué, Buenos Aires. Apesar das incursões pelo teatro e cinema, ele é mais conhecido como prosador (romances e contos) e ensaísta, sendo professor na Universidade de Princeton (Estados Unidos). Entre seus textos ficcionais estão La invasión (contos, 1967), Nombre falso (1975), Respiración artificial (1980), Prisión perpetua (1988), La ciudad ausente (1992) e Plata quemada (1997). Os livros de não ficção são Crítica y ficción (1986, comedição ampliada em 1990), Formas breves (2000), Tres propuestas para el próximo milenio (y cinco dificultades) (2001) e El último lector (2005). A loucura de suas personagens delirantes que perseguem significados secretos em textos (escritos, falados, imaginados) perpassa vários momentos de sua obra, como nos contos "La loca y el relato del crime", "El Laucha Benítez cantaba bolero" e "Prisión perpetua", e nos romances Respiración artificial e La ciudad ausente. 
movimiento típico de la vanguardia que promueve la ruptura con el mercado pero no elude las fantasías de entrar en los medios masivos. ${ }^{5}$

Em A cidade ausente, Piglia recupera a narrativa fantástica de Macedonio sobre sua mulher, Elena Obieta, que teria sido transformada em máquina. A máquina de Macedonio funciona como uma metonimia do ato de narrar. Em sua característica de multiplicar e transformar os relatos que produz, ela reflete o caráter intertextual da literatura e a concepção de que toda obra traz em si as marcas de outras obras, de que todo texto é uma tessitura de outros.

No decorrer da leitura dos múltiplos relatos que compõem A cidade ausente, o leitor percebe que a mulher/máquina está falando de si mesma e de todos, e contando sua história ela reflete sobre a Argentina. Mas vejamos mais detalhadamente como Piglia também articula sua narrativa no jogo linguístico criado pela fala louca.

Desde o conto "A louca e o relato do crime", ele trabalha com sugestão da significação plena e relevante do discurso caótico, aparentemente sem sentido, do louco. Nesse capítulo-conto, que compõe Respiração artificial, o jornalista Renzi fica encarregado de fazer a cobertura de um assassinato e se depara com o depoimento de uma moradora de rua, tida como louca. Em sua fala, a mulher não diz coisa com coisa, mas Renzi usa seus conhecimentos de linguística para "estudar" o discurso e assim acredita ter desvendado o caso. No entanto, seu editor-chefe não permite a publicação do artigo. Renzi não se inibe e começa a escrever o texto que quer ver publicado, e inicia um relato idêntico ao começo do conto - o que dá ao leitor o mesmo efeito encontrado em Pompeu: de ter lido um relato sobre o relato que ainda não foi escrito remetendo-o à leitura do texto novamente.

A ideia do discurso de um louco como mistério linguístico a ser resolvido se encontra também em $A$ cidade ausente. Gobbo já advertiu sobre a frequência da relação entre loucura e linguagem como tema central na obra de Piglia. "La idea del discurso de un loco como misterio linguístico a resolver se encuentra otra vez en Prisión Perpetua y La ciudadausente"6 (GOBBO, 2004, p. 47).

De fato, em A cidade ausente também surge, por exemplo, o hospital psiquiátrico, e nesse romance a analogia com tratamentos psiquicos, tortura e prisão na ditadura é mais presente. É o que vemos no próximo trecho citado, que se refere à sequência na qual é narrada a internação de Elena, supostamente a mulher/máquina do museu e fonte das informações de Junior. Cabe notar o clima de paranoia (mania de perseguição) que surge na construção do texto. Elena está em um fluxo intenso de memória, tendo várias lembranças e visões que se misturam com a cena do momento, que se torna uma entrevista para internação em um manicômio e, em outros momentos, um interrogatório policial. Médicos e enfermeiros transmutam-se em policiais e investigadores que querem localizar pessoas, denunciá-las. Elena fica pior e pior, pois se sente ameaçada. Na passagem, além da narrativa da internação de Elena e de sua chegada ao museu, onde supostamente ela é trancafiada e se

5 “[...] Piglia aponta em Macedonio o que poderia muito bem ser definido em seu próprio trabalho: a relação peculiar entre pensar e narrar, o estilo oral que nunca é lexical, mas, sim, que brinca com a sintaxe e com o ritmo da frase, um movimento típico da vanguarda que promove a ruptura com o mercado, mas não se furta do desejo de entrar na mídia de massa" (tradução nossa).

6 "A ideia do discurso de um louco como mistério linguístico a ser resolvido aparece também em Prisão Perpétua e $A$ Cidade Ausente" (tradução nossa). 
torna a mulher/máquina que tudo sabe, temos as divagações de Elena que trazem várias outras histórias, como a de Grete e Reyes, que, além de colaborar com o ambiente de alucinação, metaforiza, mais uma vez, a violência dos regimes ditatoriais em suas referências ao interrogatório, ao sequestro e à tortura do interrogado.

- A senhora perdeu o senso da realidade - disse Arana, como se lesse o seu pensamento. Talvez estivesse pensando alto.

- Este aqui é um lugar livre de lembranças - disse ela. - Todos fingem e são outros. Os espiões estão treinados para negar a sua identidade e usar uma memória alheia.

Pensou em Grete, que tinha se transformado numa inglesa refugiada que vendia fotos numa loja do segundo subsolo. Tinha sido infiltrada e enterrou seu passado e adotou uma história fictícia. [...]. Precisavam encontra-la, ela podia leva-los até Reyes. O Italiano quis saber quem era Reyes.

- É um professor de literatura inglesa que traficava metadona - explicou-lhe Elena. - Dirige os sanatórios clandestinos e os refúgios de desintoxicação.

Grete acreditava ter sido sua mulher em outras épocas, uma garota inglesa de Lomas de Zamora que tinha se apaixonado pelo jovem professor que dava um curso sobre E. M. Forster e Virginia Woolf. Essa história justificava seu álibi, era uma mulher desiludida que amava em segredo um homem do qual queria se vingar. Precisavam encontrá-la. [...]. Viu-se na Clínica, no teto estava o olho branco de uma câmera. Teve a impressão de que atrás dela Arena conversava com uma enfermeira. Sentiu que pegava no sono. Estava cansada demais. O Italiano agarrou-a pelo braço e a obrigou a avançar quase correndo entre os parquímetros abandonados. Era como cruzar um bosque. Nos alto-falantes tocava a banda irlandesa "The Hunger", com seu novo hino "The Reptile Enclosure". Eram os filhos dos filhos dos rebeldes nacionalistas. [...]

- Eu venho de Rosario - disse ao coreano que tomava conta da porta. - Precisamos passar. Ela é paciente do Arana.

Talvez ele fosse um policial. Todos trabalham para os serviços e se infiltram $e$ são confidentes e assassinos oficiais e ratos que injetam droga na veia para disfarçar. (Em Nova York metade dos viciados são detetives.) [...]. A loucura do parecido é a lei, pensou o Italiano. [...] As paredes brancas e os vitrais iluminados produziram uma sensação de estranha quietude. A música tinha desaparecido.

— Eis o Museu - disse o Italiano (PIGLIA, 1992, p. 62-64).

O trecho é longo, mas exemplar de vários recursos da narrativa de Piglia. Primeiramente, as múltiplas vozes gerando um efeito alucinante, pois não se sabe ao certo do que estão falando ou se o que se referem realmente aconteceu. O narrador, Elena, Arana e o Italiano revezam a voz e seus fluxos de pensamento se misturam, formando um texto uno. Em muitos momentos, fica difícil definir quem está falando. Como quando se inicia a história de Grete, "pensou em Grete [...]", o que vem a seguir é a voz de Elena, que sob depoimento delata a fotógrafa, ou é o narrador onisciente? 
Mas há outras vozes, vozes indiretas, que compõem esse texto alucinante. Como as dos romancistas E. M. Forster e Virginia Woolf. Todo o livro é atravessado por referências a outros livros e escritores. Aqui, essas duas citações remetem à renovação do gênero romance no século XX e se desdobram em metalinguagem, pois citam a fonte literária e teórica (lembremos que Forster, além de romances, escreveu ensaios) do recurso em uso na passagem: o fluxo de consciência. Uma outra voz presente confirma esse caminho: a vocalista da referida banda irlandesa The Hunger, que está tocando no rádio da clínica a canção "The Reptile Enclosure". Trata-se de Molly Malone.

Molly Malone, com dezesseis anos, liderava o grupo e com sua garganta de vidro tinha conseguido se transformar numa cantora super-star. Seu irmão Giorgio a acompanhava nos vocais com sua voz quente de tenor, mas desvairava e fazia um rap improvisado em cima dos hinos do exército republicano, mexendo nas letras das canções. A multidão delirava com a atuação ao vivo de Molly Malone. O concerto durava duas horas (PIGLIA, 1992, p. 63).

Piglia está aí (des)enrolando um longo novelo. Molly Malone é o mesmo nome de uma das personagens mais conhecidas de Dublin (Irlanda). Desde 1988, em ocasião das comemorações do primeiro milênio da cidade, ela tornou-se até estátua em via pública e parada obrigatória para todo turista fotografar. O monumento é uma homenagem à vendedora de peixes, Molly Malone, que, segundo uma canção tradicional irlandesa chamada "CocklesandMussels", percorria as ruas de Dublin cantando e vendendo peixes e mexilhões. Molly morreu jovem e seu espírito passou a assombrar as ruas da cidade gritando seu bordão, "cocklesandmussels, alive, alive!" ("moluscos e mexilhões vivos, vivos!") 7 .

Outra cantora dublinense, também chamada Molly, está mais próxima da ideia do fluxo de consciência: trata-se de Molly Bloom, personagem de Ulysses, de James Joyce, referência que atravessa a obra de Piglia. É nas últimas páginas de seu romance de 1922, que Joyce estabelece o que viriamos a chamar de fluxos de consciência ou monólogo interior.

Em seu jogo de vozes que escondem (ou revelam) outras vozes, Piglia cita diretamente Forster e Woolf e indiretamente Joyce. No entanto, nada poderia ser mais joyceano que citá-lo por meio de uma tradição oral de Dublin.

Ainda sobre o trecho, dois aspectos merecem atenção. Note-se que a imagem da escada remete à sensação de espiral que a narrativa dentro da narrativa, da memória dentro da memória, causa no leitor, transferindo para ele a aflição de Elena. E o clima de solidão, desespero e isolamento que, para alguns pesquisadores da obra de Piglia, está relacionado com seu interesse pelas personagens e autores marginais, como afirma Gobbo (2004, p. 48):

Esta cuestión de la capacidad de la loca o el loco, la facultad de manejar esa locura o no como problemática intrínseca al lenguaje, no terminaría de ser útil a los fines de la narrativa pigliana si no fuera porque ese don/maldición obliga al que lo padece a ocupar un lugar marginal, desde la reclusión en un manicomio hasta la imposibilidad de pertenecer a un sitio o al amor de una persona. Esta preponderancia de la marginalidad, de la reclusión, a menudo repre-

\footnotetext{
Trechos e referências como esses explicam por que o romance foi adaptado como ópera (gênero que Molly Bloom pratica). A obra foi uma parceria de Piglia com o músico Gerardo Gandini e estreou em 1995 no Teatro Colón, de Buenos Aires, com o mesmo título do romance, Laciudad ausente.
} 
sentada por alguna enfermedad o falencia física, es coherente con la elección de modelos literarios marginales [...]. ${ }^{8}$

E o mecanismo das múltiplas versões gerando um ruidoso discurso delirante também está presente nos relatos produzidos pela máquina. É o caso da crônica dentro do romance intitulada "A menina", que conta a história de Laura, uma garota que adquire atitudes estranhas, delirantes, e passa a acreditar que as máquinas têm vida própria e, então, começa a apresentar dificuldades com a linguagem, chegando a perder a capacidade de falar. A família toma várias providências sem recorrer à internação, mas o surto não cessa até que o pai começa a contar-lhe a mesma história com versões diferentes. A história contada centenas de vezes pelo pai tem como tema central um anel.

[...] um jovem e potentado nobre romano que acaba de se casar. Após os festejos da celebração, o jovem coloca sua aliança, com medo de perdê-la, no dedo entreaberto de uma estátua de bronze que está junto à cerca dos fundos. Ao voltar para pegá-la, constata que o dedo da estátua está fechado e que não pode tirar $o$ anel. Sem dizer nada a ninguém, volta ao anoitecer com tochas e criados $e$ descobre que a estátua desapareceu. Esconde a verdade da recém-casada e nessa mesma noite, ao entrar na cama, percebe que algo se interpõe entre os dois, algo denso e nebuloso que impede que se abracem. Paralisado de terror, ouve uma voz que sussurra em seu ouvido:

- Abraça-me, hoje tu te uniste a mim em matrimônio. Sou Vênus e me entregaste $o$ anel do amor (PIGLIA, 1992, p. 47).

Segundo o narrador do romance, a menina é a "anti-Scheherazade", pois no lugar de contar histórias, as ouve. O inusitado método dá resultados positivos, pois a estrutura circular da históriarecupera a comunicação e encerra o surto, até que um dia ela recupera a fala e pede ao pai um anel de ouro.

O método do pai é o mesmo que engendra a divulgação e permanência da literatura oral e popular: uma estrutura nuclear que permanece e variações regionais, idiomáticas e culturais que vão remodelando a história, tornando-a viva e memorável para todos que a ouvem e a recontam.

Esperava que as frases entrassem na memória de sua filha como blocos de sentido. Por isso resolveu contar sempre a mesma história e variar as versões. Desse modo o enredo era um modelo único do mundo e as frases se transformavam em modulações de uma experiência possível (PIGLIA, 1992, p. 47).

É importante notar que a tese da superação do surto que culmina com a mudez (ausência de linguagem) por meio da literatura, da ficção, contém a ideia da linguagem como elemento fundamental na constituição do sujeito. Tal tese vem ao encontro dos argumentos psicanalíticos sobre a importância da fala/ escuta/linguagem para entender e contornar as psicoses. Ecoa aí a afirmação de Foucault (1972, p. 263), de que "a linguagem é a estrutura primeira e última da loucura".

8 “Esta questão da capacidade da louca ou do louco, a faculdade de manejar essa loucura, ou não, como problemática intrínseca à linguagem, não cessa de ser útil aos objetivos da narrativa pigliana, se não fosse porque o dom/maldição obriga o doente a ocupar um lugar marginal de confinamento em um hospital psiquiátrico até a impossibilidade de pertencer a um lugar ou amar uma pessoa. Essa primazia da marginalidade, da reclusão, muitas vezes representada pela doença ou pelo defeito físico, é análoga à escolha de modelos literários marginais [...]" (tradução nossa). 
Mas as dobras não cessam. Na sequência de $A$ cidade ausente, o narrador indica a fonte da versão original do conto narrado pelo pai, "Chronicle of the Kings of England" (século XII), William de Malmesbury, depois explica que "a primeira variante de importância tinha aparecido mais ou menos vinte anos depois, numa recopilação alemã de fábulas e lendas feita em meados do século XII e conhecida pelo nome de Kaiserchronik", até indicar o "último relato da série" que seria "a versão de Henry James [...] "The LastoftheValerri"” (PIGLIA, 1992 , p. 48). E, quando a perspectiva volta para Junior, que em visita ao museu está conhecendo essa crônica que a máquina conta, o narrador ainda desdobra outras representações da mesma história, entre elas, "a gravura de Dürer ('O sonho do doutor', 1497-98)", uma "edição de The Anatomy of Melancholy, com notas manuscritas e desenhos" (PIGLIA, 1992, p. 49). Textos sobre textos.

\section{PARA NÃo CONCluIR}

As múltiplas versões trazem um outro tema constante em ambas as obras: o diálogo entre original e cópia. Para Junior, todos os textos possuem um significado e devem ser registrados e analisados à exaustão. Para Quatro-Olhos, apenas um texto é importante - o do manuscrito. Claro que para recuperá-lo é preciso confeccionar outros, mas ele não perde de vista o texto inicial como o verdadeiro, o autêntico.

Enquanto Quatro-Olhos fica obcecado por recuperar o manuscrito perdido, ele compõe e reescreve outras obras que repetem e duplicam a original. Em Piglia, há configuração análoga. Masiello (2004) indica essa questão ao notar a frequência com que Piglia utiliza elementos próprios da ação de copiar e duplicar versões em seu romance. Além da Máquina principal, de onde emanam as histórias, há várias outras máquinas copiadoras: gravadores, rádios, televisores, mapas, espelhos, tatuagens.

Ao copiar a "realidade", Junior e Quatro-Olhos parecem querer alterá-la, buscam um novo enredo, e é nesse compasso que a fala louca aparece como recuperação do discurso e da representação autêntica da experiência frente à banalidade que o mundo contemporâneo impõe à percepção e à vida das pessoas.

Nesse sentido, ecoo e amplio para Quatro-Olhos a afirmação de Idelber Avelar (2004) a respeito de A cidade ausente ser sobre a necessidade de narrar. De fato, para ambos os romances, narrar ganha a dimensão da urgência, é uma questão de vida ou morte. No livro argentino, produzir réplicas e recombinar histórias é um modo de anular a morte, seja a morte de Elena (em homenagem a Macedonio), seja a morte dos 30 mil argentinos vítimas da ditadura. No livro do brasileiro, a morte, o desaparecimento a ser superado é o da esposa de Quatro-Olhos e, metonimicamente, das vítimas da ditadura militar.

Outro ponto comum e relevante a ser notado é a importância da mulher, ou melhor, da perda da mulher amada, bela e inteligente como o centro irradiador das tramas. Iglesia (2004, p. 108) afirma:

En La ciudad ausente es Elena la que resume y asume como personaje femenino todos los saberes, todas las figuras, todas las madres, todas las hijas, todas las amantes. También es la que muere pero será eterna: El museo de la novela eterna, la novela de Macedonio Fernández; el escritor que, convertido en personaje de Piglia, pierde a su mujer y para no enloquecer construye una 
máquina femenina que es como la ficción, como la literatura, el eterno reservorio de la memoria. ${ }^{9}$

Para Quatro-Olhos, o desaparecimento e possivel morte da mulher é o desencadeador de sua loucura e, consequentemente, de seu relato.

Quatro-Olhos perambula pela cidade de São Paulo em busca de seus escritos, perseguindo folhas soltas que as pessoas dizem ter visto em bairros diversos, servindo aos objetivos mais banais, como embrulhar carne ou simplesmente jogadas no lixo. Sendo assim, ele não concorda com o termo "deambulação", pois conota andar sem rumo, e ele tinha um objetivo claro, reaver seu livro. Ou seria sua vida?

No último capítulo, "De volta", é narrada a seção psiquiátrica ou psicanalitica, isso não fica claro, que deve encaminhar sua alta. Durante essa conversa com o médico, ele elabora que o motivo de seu surto não foi a perda do livro, mas o fato de não ter acompanhado a mulher na fuga. "[...] a fuga de minha mulher precipitou as coisas. Não tanto a fuga, mas minha reação diante dela. [...] Eu não disse: 'Eu vou com você"' (POMPEU, 1976, p. 185).

Desse modo, a impossibilidade do resgate do manuscrito coloca-o no jogo de lembrar para esquecer. Além de caminhar em busca da obra roubada, ele passa seu tempo tentando lembrar o que tinha escrito para então reescrever o livro. Caminhar pela cidade, lembrar e reescrever são atividades que afastam o pensamento de sua verdadeira dor: o paradeiro da esposa, à época limitado à clandestinidade, à tortura ou à morte.

Para além do debate sobre a loucura, a analogia entre o literário e o conhecimento psicanalítico se dá aqui também no conceito de lembrança encobridora. Trata-se de uma estratégia do sistema psíquico e da memória para preservar o sujeito de sentir desprazer. Assim, no lugar de alguma lembrança perturbadora, encaixa-se uma recordação insignificante ou disparatada. O importante é que ambas as lembranças, a encobridora e a encoberta, estejam associadas em alguma medida (FREUD, 2006). O que conecta o livro e a esposa de Quatro-Olhos é o fato de terem desaparecido simultaneamente por culpa do regime militar. Pensar no livro e procurá-lo é um modo menos doloroso de procurar, ou pensar na esposa.

O que se quer ressaltar com isso é que o principal mecanismo de subversão da morte nesses romances é a duplicação. Ao espelhar personagens e situações, Junior e Quatro-Olhos alongam e perpetuam a memória e presença de quem já se foi.

É nesse intento que o primeiro relato da máquina de Macedonio, reproduzido em A cidade ausente, é sobre o duplo irredutivel à unidade. A história remete ao conto de Poe, William Wilson, que narra como a personagem principal fica incomodada com a presença do duplo ao ponto de assassiná-lo e, por fim, matar a si mesmo. Em Piglia, a Máquina conta a história de Stephen Stevensen, um duplo moderno que vem como filho de desertor, bastardo, periférico, estrangeiro. "Stevensen tinha nascido em Oxford e todas as linguas eram sua lingua materna" (PIGLIA, 1992, p. 103). E aí outra duplicação: o nome da personagem remete ao Ulysses de Joyce (Stephen Dedalus). Analogamente, Quatro-Olhos

9 “Em A cidade ausente é Elena quem resume e assume a personagem feminina e todo o conhecimento, todas as figuras, todas as mães, todas as filhas, todas as amantes. Ela também é a que morre, mas permanece eterna: $O$ museu do romance da eterna, o romance de Macedonio Fernández; o escritor que, convertido em personagem de Piglia, perde sua esposa e para não enlouquecer constrói uma máquina feminina que é como a ficção, como a literatura, o eterno reservatório de memória" (tradução nossa). 
desdobra a perda do manuscrito com o desaparecimento da esposa, como analisado anteriormente. E marca em seu nome-apelido a duplicação da visão. Um apelido comum para quem usava óculos, mas que no romance ganha outras dimensões, como a necessidade de uma visão dupla para entender a "realidade" e, simultaneamente, as perspectivas que se sobrepõem instaurando o caos.

Sobre o apelido, é interessante notar a questão da perda do nome próprio. Idelber Avelar (2004, p 187) estabelece que esse é um dos pontos fulcrais da obra de Piglia:

En uno de los cuentos intercalados, una mujer abandona a su familia, viaja, alquila una pieza de hotel va a un casino, gana una fortuna, vuelve al hotel y se suicida [...] Al alquilar la pieza, se anota con el nombre falso que no pudiera despertar sospechas, como si robarle el nombre a aquélla que la ha nombrado fuera la metáfora definitiva de lo que está en juego en la pérdida del nombre proprio. ¿Cómo aprender a perder el nombre proprio?, he ahí la pregunta central que se dicen las personajes de Piglia. ${ }^{10}$

De fato, apenas o louco pode verdadeiramente perder o nome próprio, pois, como afirmou Lacan (2008, p. 147), "o homem de nervo sadio, o sujeito normal é aquele que se coloca na posição de não levar a sério a maior parte de seu discurso interior". O louco de Piglia e de Pompeu busca o significado nas palavras levando em consideração a outra realidade, a psíquica, e ser novamente renomeado pode representar mais que o nome do berço. Eles buscam uma nova forma de existir, desejam outra vida, outra história, mas, para poder interferir na trama, alteram o enredo. Nessas obras, a busca pela comunicação autêntica não cessa. Cabe ao leitor interpretá-la.

\section{The madness made literature in Renato Pompeu and Ricardo Piglia}

Abstract: This paper articulates a reading on Quatro-Olhos, by Renato Pompeu, and A cidade ausente, by Ricardo Piglia, aiming to point how the novelists structure their fictions in the confluence between literature and madness. Through these foldstheyboth transgress the conventional narrativity and establish their books in fragmentation, in verbiage, made in textual multiplicity, and in the apparent chaos of mad talk.

Keywords: Literature and madness. Renato Pompeu. Ricardo Piglia.Quatro-Olhos. A cidade ausente.

\section{REFERÊNCIAS}

AVELAR, I. Máquina apócrifa, alegoría del duelo y poética de la traducción. In: PÉRSICO, A. R. (Org.). Ricardo Piglia: una poética sin limites.Pittsburgh: Instituto Internacional de Literatura Ibero-Americana, 2004. p. 177-200.

10 “Em uma das histórias encaixadas, uma mulher abandona sua família, viaja, aluga um quarto de hotel, vai a um cassino, ganha uma fortuna, volta ao hotel e comete suicídio [...] Ao alugar o quarto, ela se registra com um nome falso para não despertar suspeitas, como se roubar o nome daquela que a nomeou fosse uma metáfora definitiva do que está em jogo quando se perde o nome próprio. Como aprender a perder o próprio nome? - essa é a pergunta central que os personagens de Piglia se fazem" (tradução nossa). 
DALGALARRONDO, P. Psicopatologia e semiologia dos transtornos mentais. Porto Alegre: Artmed, 2000.

FELMAN, S. Writing and madness. Ithaca: Cornell University Press, 1985.

FORNET, J. Conversación imaginaria con Ricardo Piglia. In: RODRIGUEZ PÉRSICO, A.; FORNET, J. (Org.). Ricardo Piglia: una poética sin limites. Pittsburgh: University of Pittsburgh, 2004.

FOUCAULT, M. História da loucurana Idade Clássica. Tradução José Teixeira Coelho Netto. São Paulo: Perspectiva, 1972.

FREUD, S. ESB - sobre a psicopatologia da vida cotidiana. Tradução e coordenação geral de Jayme Salomão. Rio de Janeiro: Imago, 2006 [1901]. v. VI.

GOBBO, M. Autobiografía de un estilo. In: PÉRSICO, A. R. (Org.). Ricardo Piglia: una poética sin límites. Pittsburgh: Instituto Internacional de Literatura Ibero -americana, 2004. p. 41-54.

LACAN, J. Função e campo da fala e da linguagem em psicanálise. In: LACAN, J. Escritos. Tradução Vera Ribeiro. Rio de Janeiro: Jorge Zahar, 1998. p. 238-324.

LACAN, J. Seminário 3 - as psicoses. Versão brasileira de Aluisio Menezes. Rio de Janeiro: Jorge Zahar, 2008.

MASIELLO, F. Traducir la historia. In: PÉRSICO, A. R. (Org.). Ricardo Piglia: una poética sin limites. Pittsburgh: Instituto Internacional de Literatura Ibero-americana, 2004. p. 147-160.

PIGLIA, R. A cidade ausente. São Paulo: Iluminuras, 1992.

PIGLIA, R. Formas breves. São Paulo: Companhia da Letras, 2000.

POMPEU, R. Quatro-Olhos. São Paulo: Editora Alfa-Omega, 1976.

SPERANZA, G. Autobiografia, crítica y ficción: Juan José Saer y Ricardo Piglia. In: PÉRSICO, A. R. (Org.). Ricardo Piglia: una poética sin limites. Pittsburgh: InstitutoInternacional de LiteraturaIbero-americana, 2004. p. 29-40.

Recebido em abril de 2016. Aprovado em novembro de 2016. 